Scientific Journal Warsaw University of Life Sciences - SGGW

Problems of World Agriculture volume 18 (XXXIII), number 2, 2018: 218-227

DOI: $10.22630 /$ PRS.2018.18.2.49

Mateusz Mierzejewski $^{1}$, Magdalena Lampart ${ }^{2}$

${ }^{1}$ Cracow University of Economics, Poland

${ }^{2}$ University of Warsaw, Poland

\title{
Analysis of Business Cycles in the Breeding of Pigs, Cattle and Poultry and their Relationship to the Causality of Wheat and Rye Cultivation in Poland
}

\begin{abstract}
The article presents a study on the phenomenon of pig gaps in the perspective of pig, cattle, and poultry farming in Poland. The work attempts to define the phenomenon itself as well as to show the reasons for its occurrence and significance for the Polish economy. The study used a cross-spectral analysis, which indicated cyclical relationships and shifts between the studied time series. The methodology of the work was based on a simplified spectral analysis, i.e. the use of the square of coherence, spectral density and phase spectrum. In addition, the article uses a comparative method for selected production volumes. The results were analyzed in the context of occurrence of pig cycles for breeding and cultivation. The study showed the occurrence of the relationship between pig breeding and wheat and rye cultivation.
\end{abstract}

Key words: pork cycle, hog cycle, agribusiness, breeding, cycles

JEL Classification: E30, E32, E39

\section{Introduction}

The term pork cycle describes the cyclical fluctuations in the size of the livestock markets. It is one of the so-called special cycles that have their own mechanism and run independently of general fluctuations (Zawadzka, 2006), and relates to the decisions of producers as they aim to maximize their revenues. Farmers compare revenues and costs of production and when the price of meat rises, they gain additional motivation to extend the farm. Over time the supply rises which results in a price drop. Producers lose their motivation to keep the production, so they reduce it. In the next period, this leads to a price increase again and the cycle repeats (Kwaśnicki, 2002). Agriculture is particularly vulnerable to fluctuations due to weather risks, long repayment periods and low mobility of inputs. These factors determine the occurrence of cyclical and seasonal fluctuations (Stępień, 2013).

The pig cycle has been known for many years. It can be found in $19^{\text {th }}$ century literature when it occurred in the developing areas of the United States. Along with the development of the entire country and the agricultural sector, this process spread to other places. The increased demand for pork led to stronger specialization in farming and to the increase in cereal crops as feed for breeders. Farmers were faced with the new problem, which was called the iron law of hog-corn economics ( 1 bushel of corn $=10$ pounds of a pig). This dependence led to the increased importance in the relation of the prices of meat to fodder;

\footnotetext{
${ }^{1}$ MA, Department of Strategy Management and Organization Development, 27 Rakowicka St., 31-510 Kraków, e-mail: mat.mierzejewski@gmail.com; https://orcid.org/0000-0001-8542-2373

${ }^{2}$ BA; Faculty of Economic Sciences, University of Warsaw, e-mail: magd.lampart@gmail.com
} 
based on that, farmers decided when to increase and reduce production. Further development of research on the cycle took place in 1920s and 1930s. During this period "The Cobweb Theorem" by Ezekiel was published, which is one of the most important works on this topic. He explained the market adjustment mechanism which has been used many times to explain the hog cycle (Stępień, 2013). The pig cycle is not the only example of a special cycle. There is research literature for other cycles regarding bovine, fruit, and rubber (Siekierski, 2012).

As part of this work, attention was paid to seasonal fluctuations. They are on the slope of research and are often considered as interference, so data is cleaned out of them. There is also an approach that assumes the significance of these fluctuations, and the results of the research indicate their similarities with cyclical changes. An important part of the analysis is the identification of the causes of these fluctuations. Among the most important are: changes in preferences, weather conditions, holidays and expectations of consumers and producers. Empirical analysis indicates that most macroeconomic variables are subject to seasonal fluctuations, and thus it is an important element of the entire economy (Rembeza, 2017).

Pork is a significant part of the meat market and it is the biggest compared to poultry and beef. What's worth adding is the fact that the production all over the world is constantly growing but because of the rising costs, it has become highly competitive. Pork production is mainly focused on the local markets, so it is worth looking into one of the local markets. (Dybowski, Rycombel, 2011). Pork is deeply rooted in Polish culture, cuisine, and tradition. Poland is in the group of the largest producers and exporters of pork in Europe (Stępień, Czyżewski, 2013). Currently, research into the hog cycle in Europe is modest, disproportionate to the seriousness of the problem (Zawadzka, 2006). After 10 new countries joined the EU in 2004 there was a big change in the functioning of agricultural markets. They merged into one big chain of industries, and the producers had to learn to compete with others all over again.

The conducted research in this area indicated that for the Polish agricultural market the phenomenon of cyclical breeding is increasingly synchronized with the entire EU market, and thus is more and more important for the Polish agricultural market. Moreover, a growing euro-dollar exchange rate is observed, which may worsen the situation of European farmers, due to declining competitiveness. To strengthen its market position, it is worth focusing on understanding the production cycle and the factors behind its shifts (Olszańska, 2016). Using cross-spectral analysis an attempt was made to find a relationship between the sales volume of meat and grain. In addition to analysis of pork sales in Poland, it was examined whether similar shifts occurred in the beef, poultry, wheat and rye markets.

\section{Research methodology}

One of the tools that can be used to study the cyclical relationships of two-time series is spectral analysis. It helps to show fluctuations of various lengths - seasonal or business fluctuations. This method consists in decomposing a time series into several sine and cosine functions with different periods, thus enabling the most important fluctuation frequencies that have different (but significant) effects on the overall dynamics and the amplitude of the series (Osińska, 2006). Thanks to this analysis, several cycles with different periods and 
amplitudes and with different contributions to the overall dynamics of the series can be examined in a given time series (Łuczyński, 2015).

Spectrum estimation is based on a set of empirical observations for the time series $\left\{y_{t}\right.$ $: \mathrm{t}=1,2, \ldots, \mathrm{T}\}$, based on which the inference of the stochastic process $Y_{t}$.is carried out. One method of estimating the spectrum is to use the discrete Fourier transform, which for the series $\left\{y_{t}: \mathrm{t}=0,1, \ldots, \mathrm{T}-1\right\}$ is defined (and for $\mathrm{s}=0,1, \ldots, \mathrm{T}-1$ ) as:

$$
x_{s}=\sum_{T=0}^{T-1} y_{t} e^{-2 \pi i s t / T}
$$

After the Fourier transform, the Preseval equality was demonstrated (Talaga, Zieliński, 1986). Therefore, the periodogram function of the studied process can be described by the following formula:

$$
f\left(w_{s}\right)=\frac{1}{2 \pi}\left(\gamma_{0}+2 \sum_{j=1}^{T-1} \gamma_{j} \cos \left(j w_{s}\right)\right)
$$

where consecutive $\gamma_{j}$ (for $\mathrm{j}=0,1, \ldots, \mathrm{T}-1$ ) are values of autocorrelation coefficients in the attempt. In order to examine the relationship between two variables, it is necessary to analyze the stationary reciprocal spectrum (i.e._cov $\left.\left(x_{s} ; y_{s+j}\right)=\operatorname{cov}\left(x_{t} ; y_{t+j}\right) \forall(s, t, j)\right)$ of the two-dimensional process $\left[\begin{array}{l}x_{t} \\ y_{t}\end{array}\right], \mathrm{t} \in \mathrm{N}$. The spectrum function of such a process has the form:

$$
f(\omega)=\left[\begin{array}{ll}
f_{x x}(\omega) & f_{x y}(\omega) \\
f_{y x}(\omega) & f_{y y}(\omega)
\end{array}\right]=\frac{1}{2 \pi} \sum_{j=-\infty}^{\infty} e^{-i \omega j} \Gamma(j)
$$

$\Gamma(j)$ is the function of autocovarianity of the discussed process that equals $\left[\begin{array}{ll}\gamma_{x x}(j) & \gamma_{x y}(j) \\ \gamma_{y x}(j) & \gamma_{y y}(j)\end{array}\right], \quad$ where $\quad \gamma_{x x}(j)=\operatorname{cov}\left(x_{t} ; x_{t-j}\right), \quad \gamma_{x y}(j)=\operatorname{cov}\left(x_{t} ; y_{t-j}\right), \gamma_{y y}(j)=$ $\operatorname{cov}\left(y_{t} ; y_{t-j}\right), \gamma_{y x}(j)=\operatorname{cov}\left(y_{t} ; x_{t-j}\right)$ (Luczyński, 2015). The diagonals of the spectral function of the discussed two-dimensional process are: the density of one-dimensional processes $\left(x_{t}, y_{t}\right)$, which take the values respectively: $f_{x x}(w)=\frac{1}{2 \pi} \sum_{j=-\infty}^{\infty} \gamma_{x x}(j) e^{-i w j}$, $f_{y y}(w)=\frac{1}{2 \pi} \sum_{j=-\infty}^{\infty} \gamma_{y y}(j) e^{-i w j}$ and functions of mutual spectral density $f_{x y}(w)=$ $\frac{1}{2 \pi} \sum_{j=-\infty}^{\infty} \gamma_{x y}(j) e^{-i w j}, f_{y x}(w)=\frac{1}{2 \pi} \sum_{j=-\infty}^{\infty} \gamma_{y x}(j) e^{-i w j}$

The calculations also used a coefficient of multiple coherence allowing to indicate the frequency components of two-time series that are correlated with each other. It takes values from 0 to 1 .

In summary, the cross-spectral analysis was used to clarify the relationships occurring in the examined market. Based on the obtained results, the most important turned out to be the outcome of the coherence coefficient. The high value of it indicates the significance of a 
given frequency for the studied relationship of the two-time series. In the next step, the results of spectral density values of series were reviewed - their high value indicates the importance of a given frequency in shaping the overall dynamics of a given series. The last step was to calculate the values of time shifts for selected frequencies, which made it possible to assess the causality of the analyzed relationships.

\section{Study of dependence in wheat and rye crops and selected types of breeding}

The analysis included data on the purchase volumes of wheat, rye, and poultry, pig and cattle livestock. The data was downloaded from the Central Statistical Office in Poland and includes monthly values in the period from January 2012 to February 2017, which resulted in a total of 62 monthly observations. These values of individual variables are expressed in quintals $\underline{(100 \mathrm{~kg})}$.

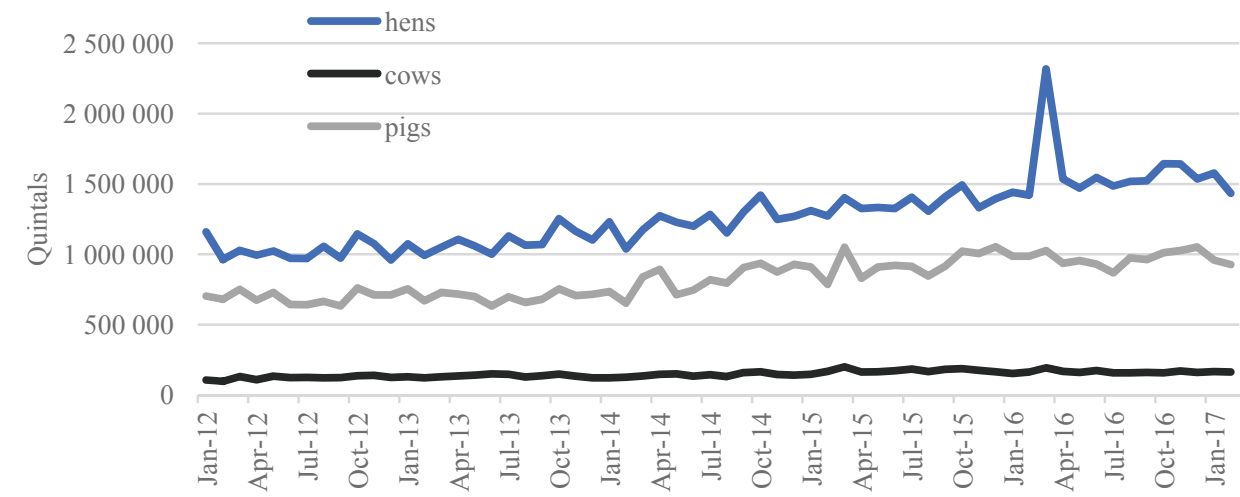

Fig. 1. Sales volume of broilers, cattle, and pigs' livestock counted in quintals

Source: Authors' study based on GUS data, Central Statistical Office http://stat.gov.pl/.

As is illustrated in Figure 1, the sales volume of meat increased over the years. From January 2012 to January 2017, in the case of broilers and pigs, sales increased by over 36\% (for chickens the values increased from 1,158,463 to 1,576,852 quintals, and for pigs values from 703,445 to 958,536 quintals), and for cattle over $55 \%$ (from 106,788 to 166,414 quintals). Meat sales volumes remain at a similar level throughout the year. Moreover, the average sales figures and standard deviations were, respectively $1,267,756$ and $1,267,756$ quintals for chickens, 827,820 and 131,596 quintals for pigs and 148,025 and 21,784 quintals for cattle.

As is illustrated in Figure 2, sales volumes for wheat and rye are more sensitive to changes throughout the year. The standard deviations are 490,099 quintals for rye and

2, 270,140 quintals for wheat. Average sales are 610,368 quintals for rye and $4,480,156$ quintals for wheat. In addition, over the years, sales of wheat increased from January 2012 to January 2017 from 163,644 to 348,420 quintals, an increase of $113 \%$, while for rye this increase was observed at $52 \%$, from 3,223,461 to $4,285,979$ quintals. 


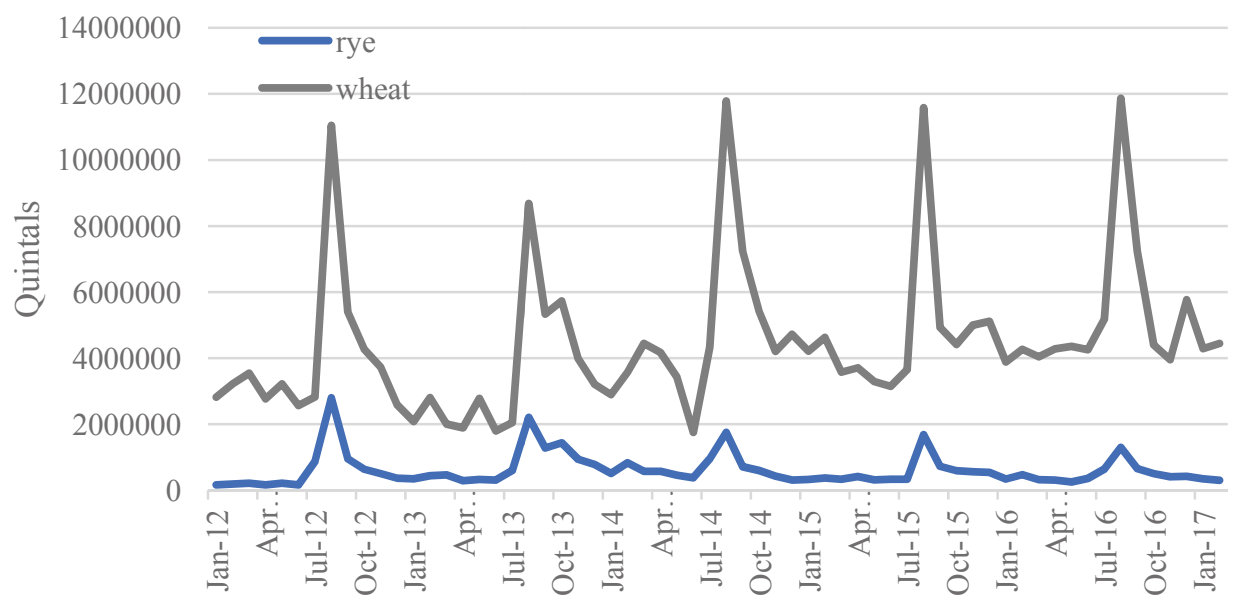

Fig. 2. The sales volume of rye and wheat calculated in quantiles

Source: Authors' study based on GUS data, Central Statistical Office http://stat.gov.pl/.

To perform spectral analysis, a trend line was determined for individual data series, and the theoretical results of the trend were removed from the empirical values. To verify the stationarity of the data prepared in this way, the Philips-Perron test was used, the result of which indicated the stationarity of all the examined series.

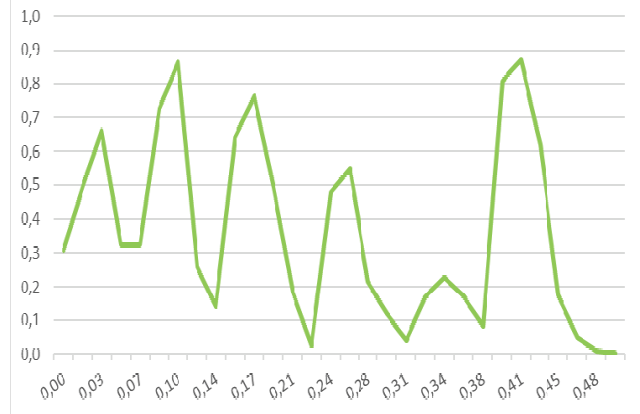

Fig. 3. Square of coherence of the cross-spectrum of sales of pigs and wheat

Source: Authors' study based on GUS data, Central Statistical Office http://stat.gov.pl/.

As can be seen in Figure 3, a significant dependence of variables can be observed for three frequencies: $0.10,0.17$ and 0.41. Similar conclusions can be observed in Figure 4, where the spectral densities of the variables studied are shown. These frequencies correspond to the significance of annual, twenty-month and four-year dependencies for the relation between the size of pig production and wheat crop. 


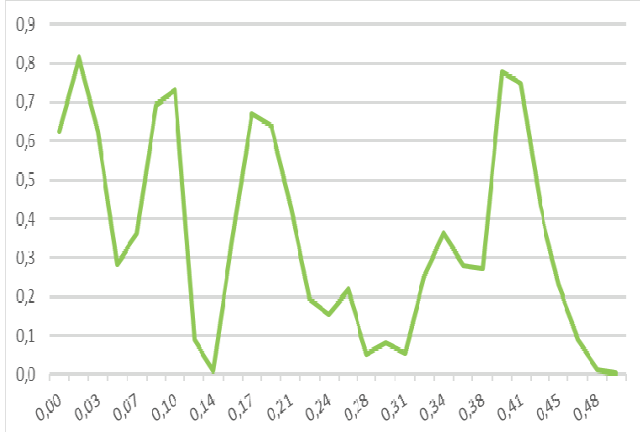

Fig. 5. Square of coherence of the cross-spectrum of sales of pigs and rye

Source: Authors' study based on GUS data, Central Statistical Office http://stat.gov.pl/.

In the case of relations between pig breeding and rye cultivation, high values of the coherence square in Figure 5 are observed for the following frequencies: 0.02, 0.10, 0.17 and 0.41 . However, in the case of the first value (0.02), the result of the spectral density for pigs is clearly lower than in other frequencies, which suggests the necessity to reject the significance of this frequency in the studied relation.

Table 1. Values of monthly delays in the sale of pigs in relation to the sale of wheat and rye for selected frequencies

\begin{tabular}{l|rrrrrr}
\hline & \multicolumn{3}{|c}{ Wheat } & \multicolumn{3}{c}{ Rye } \\
\hline Frequency & 0,1 & 0,17 & 0,41 & 0,10 & 0,17 & 0,41 \\
Length of the period & 12 & 20 & 48 & 12 & 20 & 48 \\
Value of the square of coherence & 0,86 & 0,76 & 0,87 & 0,73 & 0,67 & 0,75 \\
Delay (-) / Advance (+) & 6,39 & 3,27 & $-0,57$ & 6,36 & 3,98 & $-0,58$ \\
\hline
\end{tabular}

Source: Authors' study based on GUS data, Central Statistical Office http://stat.gov.pl/.

The results regarding selected frequencies presented in Table 1 indicate that in the case of wheat crops, annual and twenty-month changes in production volume have an impact on pig production, respectively, half-yearly and quarterly. However, the four-year fluctuations suggest that the change in the production of pigs is preceded by a change in the size of wheat crops for these frequencies by nearly half a month. It is worth emphasizing that the reliability of the results of the conducted analysis for high frequencies is subject to a higher error, therefore the recorded relation (for the frequency of 0.41 ) may be questioned. Similar results were obtained from the study of pig breeding and rye crops in Poland. They indicate the significance of the same frequencies in relation and very similar delay lengths (the biggest difference is noticeable in the case of twenty-month periods, where the value differs about 0.7 months), which indicates the occurrence of the same cyclical relationships for the analyzed relationship. For cereals examined, there was also a difference in the value of the square of coherence, which may suggest a slightly stronger relationship between breeding of pigs and the cultivation of the wheat. 


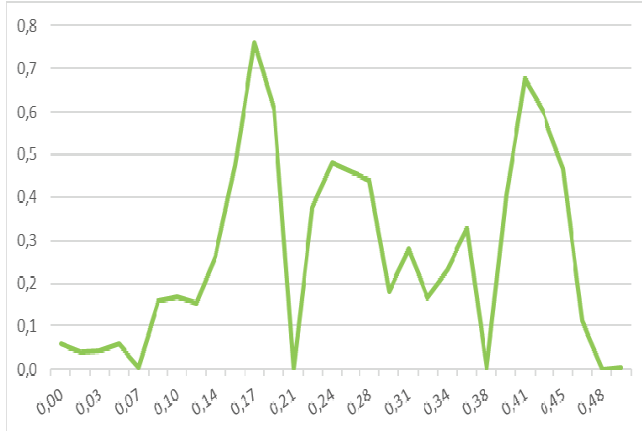

Fig. 7. Square of coherence of the cross-spectrum of sales of broilers and wheat

Source: Authors' study based on GUS data, Central Statistical Office http://stat.gov.pl/.

Analysis of the cross-spectrum coherence square plot for chicken and wheat crop cultivation indicates two significant frequencies: 0.17 and 0.41 . The significance of the first value finds its confirmation in the magnitude of spectral densities of individual variables (the marked increase in these values), however in the case of the second value (0.41), the relationship between hen breeding and wheat cultivation for these frequencies may be subject to doubts not only due to the length of the period but due to the low-density values of individual spectra.
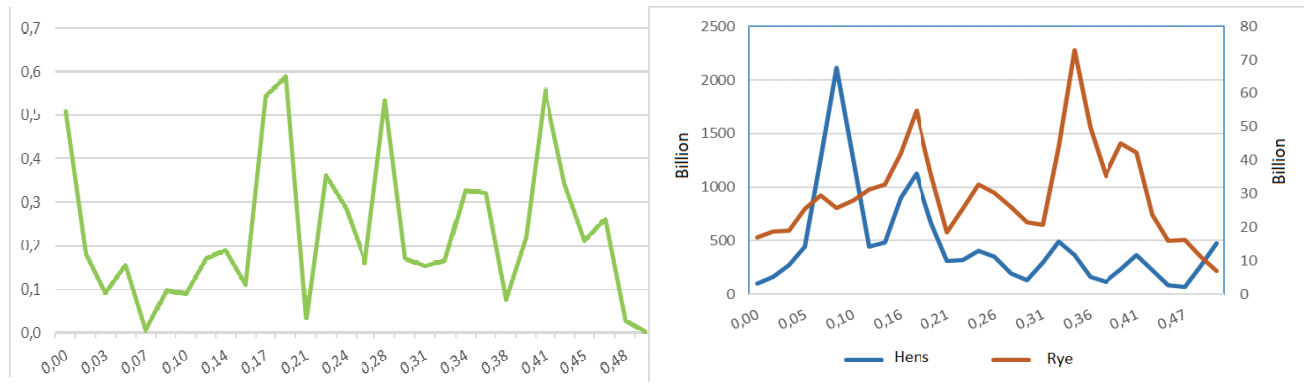

Fig. 9. Square of coherence of the cross-spectrum of sales of broilers and rye

Source: Authors' study based on GUS data, Central Statistical Office http://stat.gov.pl/.

Similar to the results of the coherence of broilers and wheat farms, the results of this index for broilers and rye farms signal two significant frequencies: 0.19 and 0.41 . However, the values of density of broilers and rye crops indicate that only the former value of the frequency is significant in the studied dependence.

The study of cyclic dependencies between wheat and rye cultivation and breeding of broilers showed that there are about twenty-monthly cycles, for which the size of cereals (both wheat and rye) are ahead of nearly three months changes in comparison with the size of the farm. 
Table 2. Values of monthly delays in the sale of broilers in relation to the sales of wheat and rye for selected frequencies.

\begin{tabular}{|c|c|c|c|}
\hline Values & \multicolumn{2}{|c|}{ Wheat } & Rye \\
\hline Frequencies & 0,17 & 0,41 & 0,19 \\
\hline Length of the period & 20 & 48 & 22 \\
\hline Value of the square of coherence & 0,76 & 0,68 & 0,59 \\
\hline Delay (-) / Advance (+) & 2,74 & $-0,43$ & 2,90 \\
\hline
\end{tabular}

Source: Authors' study based on GUS data, Central Statistical Office http://stat.gov.pl/.

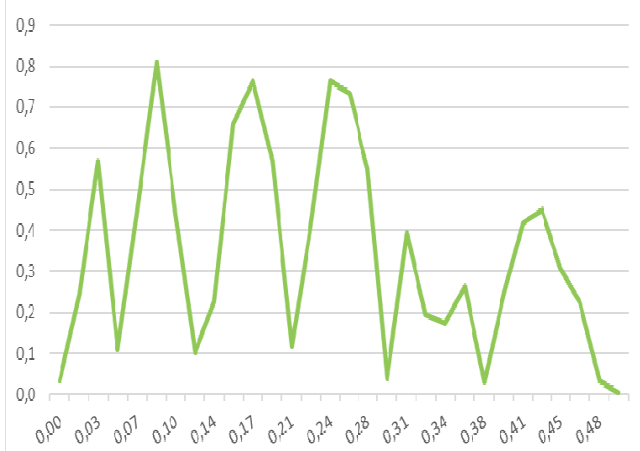

Fig. 11. Square of coherence of the cross-spectrum of sales of cattle and wheat

Source: Authors' study based on GUS data, Central Statistical Office http://stat.gov.pl/.

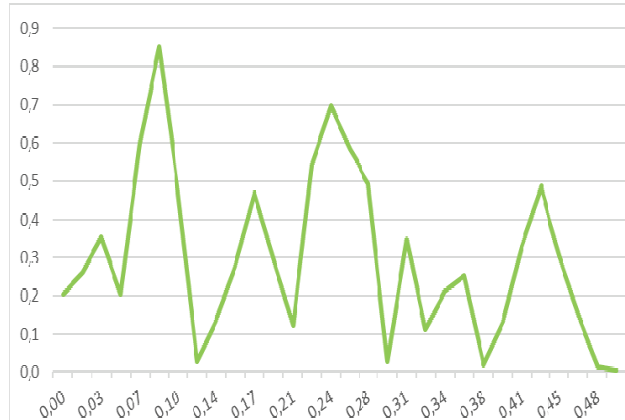

Fig. 13. Square of coherence of the cross-spectrum of sales of cattle and rye

Source: Authors' study based on GUS data, Central Statistical Office http://stat.gov.pl/.

The results of the cross-spectrum coherence squares of cattle and wheat shown in Figure 11 indicate three important relationships: $0.09,0.17$ and 0.24 . The lowest frequency
Fig. 12. Spectral density of cattle and wheat

Source: Authors' study based on GUS data, Central Statistical Office http://stat.gov.pl/.

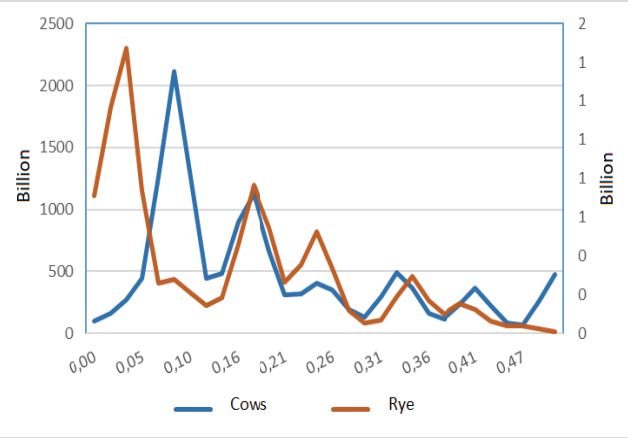

Fig. 14. Spectral density of cattle and rye

Source: Authors' study based on GUS data, Central 
(0.09) must be rejected due to the fundamental differences in the spectral density of individual variables.

As shown in Figures 13 and 14, the coherence square indicates two frequencies important for the relation: 0.09 and 0.24 . However, due to the inconsistency between the density values of the spectra of individual variables, the lower frequency should be rejected. There are also doubts about indicating the frequency of 0.24 as significant for the relation also due to low (but consistent) density values.

Table 3. Values of monthly delays in the sale of cattle in relation to the sales of wheat and rye for selected frequencies.

\begin{tabular}{l|ccr}
\hline \multicolumn{1}{c|}{ Values } & \multicolumn{2}{c}{ Wheat } & Rye \\
\hline Frequency & 0,17 & 0,24 & 0,24 \\
Length of the period & 20 & 28 & 28 \\
Value of the square of coherence & 0,76 & 0,76 & 0,70 \\
Delay (-)/ Advance (+) & 2,89 & $-3,42$ & $-3,51$ \\
\hline
\end{tabular}

Source: Authors' study based on GUS data, Central Statistical Office http://stat.gov.pl/.

Study of the relationship between wheat and rye cultivation and breeding of broilers showed significant relationships for frequencies equal to 0.17 and 0.24 , which corresponds respectively to 20-month and 2-year relationships. In the case of a lower frequency, the delay value is about three months, which may indicate the existence of dependence of annual cycles in wheat cultivation and cow breeding.

\section{Summary}

As expected, an empirical study using cross-spectral analysis showed the occurrence of pig gap phenomena in the wheat - rye and pig - breeding relationship. Depending on the length of the cycles (annual and twenty-months) significant and semi-annual shifts were observed. It is worth emphasizing that this relationship is stronger for annual cycles (and quarterly shifts) as well as for the relationship between wheat growing and pig breeding.

To summarize:

- The study showed that there are dependencies for twenty- month cycles between wheat growing and breeding of broilers and cattle. As in the case of pigs, the delay in these relations is approximately three months,

- The relation between rye cultivation and the breeding of broilers and cattle indicated the existence of dependent annual cycles, with an offset of approximately three months,

- The occurrence of pig gaps in Poland for wheat and rye cultivation and pig breeding was confirmed.

The data indicates, therefore, the existence of long-term dependencies for breeding chickens and cattle, and selected crops, however, breeding cycles are most clearly visible in the relationship between pig farms and selected crops, and at the same time are shorter. The phenomenon of pig gaps is, therefore, a characteristic phenomenon only for a selected type of breeding - pigs. 


\section{Bibliography}

Dybowski, G., Rycombel, D. (2011). Światowy rynek wieprzowiny i drobiu na tle bilansu zbóż i pasz (The world market of pork and poultry on the background of cereals and fodder balance), Instytut Ekonomiki Rolnictwa i Gospodarki Żywnościowej, Państwowy Instytut Badawczy.

Kwaśnicki, W. (2002). Cykl świński - próba modelowania i analizy (Pig cycle, a modeling and analysis attempt), Instytut Nauk Ekonomicznych, Uniwersytet Wrocławski.

Łuczyński, W. (2015). Zastosowanie analizy widma wzajemnego w badaniu dynamiki indeksu giełdowego (Application of the mutual spectrum analysis in the study of the stock index dynamics). Studia Oeconomica Posnaniensia, 3(9), 19-56.

Olszańska, A. (2016). Wielkość skupu i ceny skupu żywca wieprzowego w Unii Europejskiej w latach 1990-2015. Analiza zmian na przykładzie wybranych krajów (Volume of purchase and prices of pigs in the EU in 1990 - 2015. Analysis of changes on the example of selected countries). Roczniki Naukowe Stowarzyszenia Ekonomistów Rolnictwa i Agrobiznesu, 18(3), 279-284.

Olszańska, A. (2017). Zmiany wielkości produkcji wieprzowiny i jej struktury w Unii Europejskiej ze szczególnym uwzględnieniem pozycji krajów przyjętych po $2004 \mathrm{r}$. (Changes in the size of pork production and its structure in the European Union, with particular emphasis on the position of the countries that joined the EU after 2004), ZN SGGW Problemy Rolnictwa Światowego, tom 17(2), 166-175.

Osińska, M. (2006). Ekonometria finansowa (Financial Econometrics), PWE, Warszawa.

Rembeza, J. (2017). Sezonowość PKB i jego komponentów w krajach Unii Europejskiej (Seasonality of GDP and its components in the EU countries). Wiadomości statystyczne nr 11 (678), 17-28.

Siekierski, J. (2012). Nobliści w dziedzinie ekonomii o cyklach i kryzysach gospodarczych (Nobel Prize winners in economics on economic cycles and crises). Zeszyty Naukowe Małopolskiej Wyższej Szkoły Ekonomicznej $w$ Tarnowie, 1(20), 149-166.

Stępień, S., Czyżewski, A. (2013). Wahania cykliczne na rynku żywca wieprzowego na świecie i w wybranych krajach (Cyclic fluctations on the pig market in the world and in selected countries). Wies i Rolnictwo, 1(158), 140-157.

Stępień, S. (2013). Zróżnicowanie wahań cyklicznych na rynku żywca wieprzowego w wybranych krajach Unii Europejskiej (Differences in cyclical fluctations on the pigs market in selected EU countries). Folia Pomeranae Universitatis Technologiae Stetinensis. Oeconomica, 70, 201-212.

Talaga, L., Zieliński, Z. (1986). Analiza spektralna w modelowaniu ekonometrycznym (Spectral analysis in econometric modeling), PWN, Warszawa.

Zawadzka, D. (2006). Historia Badań „Cyklu świńskiego” (History of the „Pig's cycle” research) Instytut Ekonomiki Rolnictwa i Gospodarki Żywnościowej - PIB Warszawa.

\section{Data source}

Central Statistical Office in Poland, http://stat.gov.pl/, download date: 04.11.2017.

For citation:

Mierzejewski M., Lampart M. (2018). Analysis of Business Cycles in the Breeding of Pigs, Cattle and Poultry and their Relationship to the Causality of Wheat and Rye Cultivation in Poland. Problems of World Agriculture, 18(2), 218-227; DOI: 10.22630/PRS.2018.18.2.49 